\title{
Belief in rehabilitation and social reinsertion of prisoners is positive factor for occupational health of correctional employees
}

\section{La creencia en la rehabilitación y reinserción social de los internos de prisión como factor protector de la salud laboral de los trabajadores}

\author{
Miguel Clemente, Adela Reig-Botella, Raúl Coloma \\ Universidade da Coruña
}

\begin{abstract}
Published works demonstrate that faith in the possibility of inmate rehabilitation and social reinsertion is a positive factor for the occupational health of correctional employees, by preventing burnout syndrome. The present study investigates the effects of attitude regarding inmate rehabilitation and social reinsertion on the psychosocial health of correctional employees. 536 correctional employees from Peruvian prisons participated in the study. We collected personal information and work descriptions and assessed the employees for burnout syndrome, work satisfaction, problems conciliating work and family life, role conflict, and role ambiguity. We found that correctional employees who believed that inmate rehabilitation and social reinsertion was possible had better occupational health: increased job satisfaction, lower burnout, and greater conciliation between work and family life. However, these employees also experienced greater role ambiguity and role conflict, which decreases psychosocial health. The three variables that predicted a positive attitude towards inmate rehabilitation and reinsertion were job satisfaction, negative work-family interaction, and role ambiguity. Need for programs that clearly define the tasks of correctional workers in order to prevent role ambiguity are discussed.
\end{abstract}

Keywords: occupational health, psychosocial risks, treatment in prisons, attitudes, prisons

\section{Resumen}

La literatura demuestra que un factor protector de la salud de los trabajadores de instituciones penitenciarias es la creencia en la rehabilitación y la reinserción de los internos. Esta actitud positiva previene problemas de salud laboral al evitar, fundamentalmente, el síndrome de burnout. Este trabajo investiga si una actitud positiva o negativa hacia la creencia en la rehabilitación y reinserción de los penados provee de mayor o menor protección frente a problemas de salud psicosocial. Participaron en el estudio 536 trabajadores de prisiones peruanas. Se recogió información de variables personales y laborales, así como cuestionarios de burnout, satisfacción en el trabajo, conciliación entre vida laboral y familiar. Y conflicto y ambigüedad de rol. Los datos confirman que la creencia en la rehabilitación y la reinserción implica más salud laboral al provocar más satisfacción laboral, menor burnout y mayores niveles de conciliación entre la vida laboral y familiar, por otras parte implica más ambigüedad y conflicto de rol (deteriorando por lo tanto la salud psicosocial). Un análisis de regresión establece que las tres variables predictoras de la actitud positiva hacia la rehabilitación y la reinserción son la satisfacción laboral, la interacción negativa trabajo-familia, y la ambigüedad de rol. Se discuten los resultados y se proponen tanto futuras líneas de investigación como la necesidad de promocionar programas dirigidos a los trabajadores que definan más sus tareas, de cara a evitar la ambigüedad de rol.

Palabras clave: salud laboral, riesgos psicosociales, tratamiento penitenciario, actitudes, prisiones

Miguel Clemente, Adela Reig-Botella, Raúl Coloma, Departamento de Psicología, Campus de Elviña s/n, 15071 A Coruña, España.

Correspondencia relativa a este artículo: Miguel Clemente-miguel.clemente@udc.es 
The concept of "imprisonment" has evolved from meaning the mere containment of inmates to the protection of society plus implementation of strategies for inmate rehabilitation and eventual reinsertion into society. Although many different types of prisons exist, in accordance with the legislation for each country, there are two basic types of correctional institutions: maximum security prisons, which are specially used for inmates that pose a threat to others, and those institutions that emphasize treatments for the rehabilitation and eventual reinsertion of inmates back into society. In both types of prisons, inmates are subject to observation and control, but the control is much more rigorous in the maximum security prisons. The role and the characteristics of correctional treatments have been analyzed in classic works such as Hollin (1999) and Kifer, Hemmens, and Stohr (2003).

In order for maximum security prisons to meet their goal of protecting the community, correctional employees need to maintain order in the prisons. Their job tasks and responsibilities are clearly defined in such a way that informal relationships with inmates are unlikely and ties to the institution are strengthened. As a result, inmates implement and respect their own code of conduct, which places the inmates in a radically antagonistic position with regard to the prison employees. In contrast, prisons that primarily focus on rehabilitative treatments employ less strict security measures, implement non-punitive discipline of the inmates, and require a greater degree of personal interaction between inmates and correctional employees. However, it is more difficult to evaluate the effectiveness of rehabilitative treatments in these institutions because they are confounded by the contributions of the correctional officers themselves (Piliavin and Vadum, 1968).

Most correctional institutions emphasize a combination of both goals, which often leads to organizational conflict. Conflicts can arise between the different types of prison personnel, such as those charged with custody of the inmates and those charged with providing treatment to the inmates, due to their distinct job roles (Weber, 1957), differing priorities (goals) (Piliavin and Vadum, 1968), and differing views of the job expectations (Brown et al., 1971). For example, correctional employees in charge of security will perform control and custody tasks; however, some of these employees will perceive the goal of their job as maintaining control and custody of the inmates while others of these employees will perceive the goal of their job as rehabilitation and social reinsertion of the inmates. That is, some employees will have a positive attitude toward treatment while others will have a negative attitude in this regard, and these attitudes can be measured (Melvin, Gramling, \& Gardner, 1985; Ortet-Fabregat, Perez, \& Lewis, 1993).

Prisons in which the correctional employees experience high levels of role conflict are characterized by employees with low motivation, low adherence to treatment ideologies, and strong support for inmate custody and control. Hepburn and Albonetti (1980) found evidence that role conflict is greater in minimum security prisons and that treatment-focused staff suffered greater role conflict than custodial staff. High role conflict was associated with increased job dissatisfaction as well as dissatisfaction with the level of organizational control. Because the magnitude of the role conflict experienced by both types of employees (those who believe in the treatment and those who do not believe in it) did not differ across the different types of prisons, the authors concluded that role conflict is more strongly tied to the organizational goals of the prison rather than the specific employment positions within each organization. Therefore, prison employees who believe that rehabilitation of inmates is possible often have higher role conflict and role ambiguity, which could contribute to poorer occupational health of these employees. Affected employees experience occupational stress, job dissatisfaction, absenteeism, etc, which is ultimately reflected in their interest, motivation, and effort in managing the inmates (Schaufeli \& Peeters, 2000). Grau, Salanova, and Peiró (2000) found that employees with the highest levels of organizational commitment have a more supportive work environment, less role conflict, and greater professional self-efficacy. In fact, when role conflict was low, the level of job commitment was high in employees with either high or low professional self-efficacy. In contrast, when role conflict was high, the employees with low professional self-efficacy scored much lower on assessments of job commitment.

It seems, therefore, well established that the occupational health of prison employees can deteriorate over time, and this deterioration is mediated by variables such as job commitment. However, the role of attitudes in general and attitudes toward correctional treatment programs have been less well studied in terms of their influence on occupational health of correctional workers. Limited data are available regarding the attitudes of correctional employees towards inmates (Callahan, 2004; Carr-Walker, Bowers, Callaghan, Nijman, \& Paton, 2004; Farkas, 1999; Jurik, 1999; Kjelsberg and Loos, 2008; Kjelsberg, Skoglund, \& Rustad, 2007; Murphy \& Brown, 2000), society towards both correctional employees and inmate (Brown, 1999; Kjelsberg, Skoglund, \& Rustad, 2007), and inmates towards managers (Philiber, 1987; Reisig \& Lovrich, 1998).

Limited evidence suggests that positive attitudes regarding correctional treatment can protect the occupational health of correctional employees (Cullen, Latessa, Burton, \& Lombardo, 1993; Cullen, Lutze, Link, \& Wolf, 1989; Paboojian \& Teske, 1997). The purpose of the present study was to further assess whether or not the occupational health of correctional employees differs as a function of their attitude towards treatments for inmate rehabilitation and society reinsertion. Basis on an extensive literature review, we chose to examine burnout, job satisfaction, family interaction, and stress due to role 
ambiguity and role conflict. We hypothesized that correctional employees with a positive attitude towards rehabilitative treatments for inmates will experience less burnout syndrome, greater job satisfaction, and greater conciliation between professional and family lives, but greater role ambiguity and role conflict, compared with correctional employees who have negative attitudes towards inmate rehabilitation treatments.

\section{Method}

\section{Participants}

We attempted to evaluate the maximum possible number of employees from correctional institutions in Peru, and collected 536 questionnaires between July 2011 and January 2012. The total population of correctional employees in Peru was 5985 at the time the survey was initiated, so our sample corresponded to approximately $10 \%$ of the total employee population. This sample is incidental, not probabilistic. The majority of respondents were male $(87.75 \%)$, which is consistent with the overrepresentation of males among correctional employees. For this study, there was no control group since a relevant group with similar characteristics could not be identified. However, an internal comparison was performed, based on whether the employees had a positive or negative attitude towards inmate rehabilitative treatments.

\section{Instruments}

Data on Personal, Social, and Job-Related Matters. This brief questionnaire was useful for identifying the specific job of each employee and job characteristics, and for collecting sociodemographic data for each participant.

Brief Burnout Questionnaire. The brief burnout questionnaire was created by Moreno, Bustos, Matallana, and Miralles (1997) as an alternative to the common Maslach questionnaire (see Maslach \& Jackson, 1981), using a sample of 145 teachers from Spanish schools. The questionnaire is comprised of 21 items that assess causes of burnout (task characteristics, boredom, and the organization structure), factors of burnout syndrome (specifically emotional exhaustion), and consequences of burnout (physical, family environment, and job performance). The reliability, as reflected by the alpha index, was between .34 and .82 . Similarly, reliability on the original scale developed by Maslach generally ranges between .43 and .79, with the assessment of depersonification always showing the lowest reliability score on both questionnaires. The overall reliability on the brief burnout questionnaire was .74, which is similar to the overall reliability of .79 on the Maslach questionnaire. The scale proposed for the brief burnout questionnaire is consistent with the factors proposed by Maslach, and in the same order: personal fulfillment, emotional exhaustion, and depersonalization.
Work-Family Interaction Questionnaire. This tool was used to assess the relationships between work and personal environments. This test had previously been adapted and validated for Hispanic populations using a sample of 283 emergency first responders (Moreno, Sanz, Rodríguez-Muñoz, \& Geurts, 2009), which is a significantly smaller sample than the one we used in the present study. The questionnaire contains 22 questions that are assessed along one of four scales: negative work-family interaction, negative family-work interaction, positive work-family interaction, and positive family-work interaction. The reliability analysis indicated a good internal consistency, with values between .77 and .89 . Significant correlations were found between this questionnaire and other measures of job issues, family matters, and wellness, which provided support for its convergent validity. We conclude that this Spanish version of the questionnaire has adequate psychometric properties.

Job Satisfaction Questionnaire. Job satisfaction was measured with a questionnaire that integrated the S21/26 and S4/82 questionnaires of Meliá and Peiró (Meliá, Nogareda, Lahera, Duro, Peiró, Salanova, \& Gracia, -2006)., which has previously been used by Chiang, Salazar, and Núñez (2007). The test was originally validated using participants from six public institutions as a way to measure customer satisfaction, with a total sample size of 547 employees. Emphasis was placed on the organizational environment. The instrument has 39 questions and employs a Likert format for the responses, with six scores that range from "complete agreement" to "complete disagreement". Chiang, Salazar, and Núnez (2007) claim that the six scores had very high reliability (index scores between .80 and .90).

Role Ambiguity and Role Conflict. Role ambiguity and role conflict were measured using the scale proposed by Rizzo, House, and Lirtzman (1970). Those authors used large samples, including samples of public employees, to calculate the reliability and validity. The values for validity were always near .90 . The Spanish version of this test was created by Mansilla (2011), and it closely follows the original format, with five items that measure ambiguity and eight items that measure conflict. Responses are structured in a Likert format, ranging from 1 to 7.

\section{Procedure}

The questionnaire package contained copies of all questionnaire along with a form for informed consent, a description of the study objectives, and a reassurance that the identity of each participant would remain confidential and that the data would be used for research purposes only. Investigator contact information was also provided so that participants could ask questions about the study or revoke their consent to participate.

The questionnaire package was sent to the National Correctional Institute of Peru (INPE) along with a letter requesting permission to recruit the correctional 
employees. After an interview with INPE officials, approval was granted, and prison employees as well as employees from the central administration of the INPE were contacted. Questionnaire packages were distributed to all correctional institutions in the country. We obtained 547 respondents, corresponding to about $10 \%$ of the population. Each respondent was contacted personally after the agreement to participate.

Data were collected and analyzed with SPSS software (version 18.0). Descriptive statistics, differences in group means, and linear regression model, were calculated. The variable "belief in rehabilitation and reinsertion" was made operational through a dichotomous question that was incorporated into the questionnaire used to collect personal information and work conditions.

\section{Results}

\section{Reliability of the instruments}

We first determined whether or not the survey instruments had adequate reliability when applied to this particular population of correctional employees. Cronbach's alpha was calculated as .868 for burnout factors, .868 for burnout syndrome, and .882 for consequences of burnout. Thus, even though all three tests had high reliability, the test for consequences of burnout was slightly superior compared to the others. For the workfamily interaction questionnaire, Cronbach's alpha was .915 for negative work-family interaction, .855 for negative family-work interaction, .802 for positive work-family interaction, and .824 for positive family-work interaction. All four scales were reliable, with the greatest reliability for negative work-family interaction, and the least reliability for positive work-family interaction. Reliability for the job satisfaction questionnaire was .984 , which indicated very high reliability. The global score for role ambiguity was .909 and the global score for role conflict was .950, indicating that both scales had very high reliability.

\section{Attitude towards inmate rehabilitation and social reinsertion}

The attitude of each participant towards inmate rehabilitation and social reinsertion was determined, and $33.95 \%$ of respondents ( 1 out of every 3 ) expressed positive attitudes in this regard. Participants were then divided into two groups - those with positive attitudes and those with negative attitudes - and compared in all subsequent analyses. The descriptive statistics for each group of participants is shown in Table 1, and the results of the statistical analyses are shown in Table 2. It is important to note that homogeneity of variance could not be assumed except in the case of positive work-family interaction.

Employees who believed in rehabilitative treatments for the inmates had lower scores for all three components of burnout than those employees who did not believe in such treatments (Tables 1 and 2). On the work-family interaction questionnaire, negative work-family interaction and negative family-work interaction were lower for employees who believed in inmate rehabilitation compared to employees who did not. However, both positive interaction factors were also lower for those employees with a positive attitude towards rehabilitation compared to those who did not (Tables 1 and 2). Employees who believed in inmate rehabilitation and reinsertion had higher job satisfaction than employees that did not, but they also scored higher on both role ambiguity and role conflict (Tables 1 and 2).

Table 1.

Descriptive statistics as a function of employee attitudes towards rehabilitation/reinsertion of inmates

\begin{tabular}{|c|c|c|c|c|}
\hline & $\begin{array}{c}\text { Belief in } \\
\text { rehabilitation } \\
\text { and social } \\
\text { reinsertion } \\
\text { of inmates }\end{array}$ & Mean & $\begin{array}{c}\text { Typical } \\
\text { deviation }\end{array}$ & $\begin{array}{l}\text { Typical } \\
\text { error of } \\
\text { the mean }\end{array}$ \\
\hline \multirow{2}{*}{$\begin{array}{l}\text { Role } \\
\text { ambiguity }\end{array}$} & Yes & 26.955 & 4.729 & .354 \\
\hline & No & 21.196 & 5.899 & .3144 \\
\hline \multirow{2}{*}{ Role conflict } & Yes & 38.169 & 10.415 & .826 \\
\hline & No & 28.838 & 11.602 & .646 \\
\hline \multirow{2}{*}{$\begin{array}{l}\text { Job } \\
\text { satisfaction }\end{array}$} & Yes & 67.796 & 29.692 & 2.297 \\
\hline & No & 48.710 & 11.751 & .632 \\
\hline \multirow{2}{*}{$\begin{array}{l}\text { Negative } \\
\text { work-family } \\
\text { interaction }\end{array}$} & Yes & 13.187 & 5.662 & .426 \\
\hline & No & 17.589 & 3.561 & .190 \\
\hline \multirow{2}{*}{$\begin{array}{l}\text { Negative } \\
\text { family-work } \\
\text { interaction }\end{array}$} & Yes & 6.250 & 2.974 & .221 \\
\hline & No & 8.388 & 1.991 & .105 \\
\hline \multirow{2}{*}{$\begin{array}{l}\text { Positive } \\
\text { work-family } \\
\text { interaction }\end{array}$} & Yes & 9.227 & 2.727 & .203 \\
\hline & No & 10.481 & 2.428 & .129 \\
\hline \multirow{2}{*}{$\begin{array}{l}\text { Positive } \\
\text { family-work } \\
\text { interaction }\end{array}$} & Yes & 10.227 & 2.780 & .207 \\
\hline & No & 11.094 & 2.272 & .121 \\
\hline \multirow{2}{*}{$\begin{array}{l}\text { Burnout } \\
\text { factors }\end{array}$} & Yes & 25.393 & 3.613 & .281 \\
\hline & No & 26.220 & 1.907 & .102 \\
\hline \multirow{2}{*}{$\begin{array}{l}\text { Burnout } \\
\text { syndrome }\end{array}$} & Yes & 31.543 & 7.477 & .571 \\
\hline & No & 36.088 & 4.386 & .234 \\
\hline \multirow{2}{*}{$\begin{array}{l}\text { Consequences } \\
\text { of burnout }\end{array}$} & Yes & 10.293 & 3.342 & .251 \\
\hline & No & 12.313 & 1.709 & .090 \\
\hline
\end{tabular}

Regression analysis was performed in order to determine the contribution of each variable measured with regard to the employee beliefs about inmate rehabilitation and social reinsertion (dependent variable). Table 3 shows a summary of this model, and significance was obtained with a corrected $\mathrm{R}$ square of .473. It is, therefore, a suitable explanation model. 
Table 2.

Differences in group means as a function of employee attitudes towards rehabilitation/reinsertion of inmates

\begin{tabular}{|c|c|c|c|c|c|c|c|}
\hline Variable & $F$ & Sig. & $t$ & $d f$ & $\begin{array}{c}\text { Sig. } \\
\text { (bilateral) }\end{array}$ & $\begin{array}{c}\text { Differences } \\
\text { in means }\end{array}$ & $\begin{array}{c}\text { Typical error } \\
\text { of the } \\
\text { difference }\end{array}$ \\
\hline Role ambiguity & 22.763 & .001 & 120.153 & 430.662 & .001 & 5.759 & .473 \\
\hline Role conflict & 5.867 & .016 & 80.896 & 346.855 & 0.001 & 9.331 & 1.048 \\
\hline Job satisfaction & 366.019 & .001 & 80.009 & 191.594 & .001 & 19.086 & 2.383 \\
\hline Negative work-family interaction & 56.550 & .001 & -90.414 & 247.060 & .001 & -4.401 & .467 \\
\hline Negative family-work interaction & 42.395 & .001 & -8.701 & 263.175 & .001 & -2.138 & .245 \\
\hline Positive work-family interaction & 2.905 & .089 & -50.404 & 531.000 & .001 & -1.253 & .232 \\
\hline Positive family-work interaction & 4.113 & .043 & -3.607 & 304.419 & .001 & -.866 & .240 \\
\hline Burnout factors & 28.882 & .001 & -2.759 & 208.843 & .006 & -.826 & .299 \\
\hline Burnout syndrome & 92.043 & .001 & -7.353 & 228,989 & .001 & -4.544 & 618 \\
\hline Consequences of burnout & 121.026 & .001 & -7.559 & 223,162 & .001 & -2.019 & .267 \\
\hline
\end{tabular}

Table 3.

Summary of Linear Regression Model as a Function of Belief in Rehabilitation/Reinsertion of Inmates

\begin{tabular}{cccccccc}
\hline & & & \multicolumn{3}{c}{ Change Statistics } \\
& $R^{2}$ & Corrected $R^{2}$ & $\begin{array}{c}\text { Typical Error } \\
\text { of the } \\
\text { estimate }\end{array}$ & Change in $R^{2}$ & Change in $F$ & $d f 1$ & $\begin{array}{c}\text { Sig. Change } \\
\text { in } F\end{array}$ \\
\hline .697 & .486 & .473 & .33235 & .486 & 38.297 & 10 & 405 \\
\hline
\end{tabular}

A global significance ANOVA of the predicting variables with respect to belief in rehabilitation and reinsertion was calculated (Table 4). The high significance of the relationship was confirmed. Therefore, it is confirmed that just discussed. This is an appropriate explanatory model.

Table 4.

ANOVA showing global significance for the predictive variables as a function of belief in rehabilitation/ reinsertion of inmates

\begin{tabular}{lccccc}
\hline & $\begin{array}{l}\text { Sum of } \\
\text { squares }\end{array}$ & $d f$ & Quadratic & & \\
& mean & $F$ & Sig. \\
\hline Regression & 42.302 & 10 & 4.230 & 38.297 & .001 \\
Residual & 44.736 & 405 & .110 & & \\
Total & 87.038 & 415 & & & \\
\hline
\end{tabular}

The coefficients for each predicting variable, with respect to employee belief in inmate rehabilitation and reinsertion, are shown in Table 5. Only three variables were highly predictive of the belief in the treatment, and their order of importance was role ambiguity, negative workfamily interaction, and job satisfaction (Table 5). Specifically, correctional employees with negative attitudes regarding inmate rehabilitation and social reinsertion had low role ambiguity, low job satisfaction, and high negative work-family interaction whereas correctional employees with positive attitudes regarding inmate rehabilitation and social reinsertion tended to have high role ambiguity, high job satisfaction, and low negative work-family interaction.

Table 5.

Coefficients for each predictive variable with respect to belief in rehabilitation/reinsertion of inmates

\begin{tabular}{lccccc}
\hline & \multicolumn{3}{c}{$\begin{array}{c}\text { Non-standardized } \\
\text { coefficients }\end{array}$} & \multicolumn{2}{c}{ Typified coefficients } \\
& $B$ & $\begin{array}{c}\text { Typical } \\
\text { error }\end{array}$ & Beta & $t$ & Sig. \\
\hline (Constant) & 2.172 & .332 & & 6.550 & .001 \\
Role ambiguity & -.032 & .005 & -.439 & -6.472 & .001 \\
Role conflict & -.005 & .003 & -.126 & -1.884 & .060 \\
$\begin{array}{l}\text { Job satisfaction } \\
\text { Negative work- }\end{array}$ & -.005 & .001 & -.204 & -3.644 & .001 \\
family interaction & .040 & .008 & .382 & 4.759 & .001 \\
$\begin{array}{l}\text { Negative family- } \\
\text { work interaction }\end{array}$ & -.009 & .016 & -.046 & -.551 & .582 \\
$\begin{array}{l}\text { Positive work- } \\
\text { family interaction }\end{array}$ & .022 & .012 & .115 & 1.796 & .073 \\
$\begin{array}{l}\text { Positive family- } \\
\text { work interaction }\end{array}$ & .010 & .012 & .051 & .868 & .386 \\
$\begin{array}{l}\text { Burnout factors } \\
\text { Burnout syndrome }\end{array}$ & .001 & .008 & .007 & .156 & .876 \\
$\begin{array}{l}\text { Consequences of } \\
\text { burnout }\end{array}$ & -.026 & .007 & -.002 & -.024 & .981 \\
\hline
\end{tabular}




\section{Discussion and conclusions}

Based on the results from this study, we can not strongly conclude that correctional employees who believe in inmate rehabilitation and social reinsertion have greater occupational health or that such beliefs constitute a protective factor for their health. Even though a positive attitude can positively influence occupational health (Callahan, 2004; Carr-Walker, Bowers, Callaghan, Nijman, \& Paton, 2004; Farkas, 1999; Jurik, 1999; Kjelsberg \& Loos, 2008), a positive attitude towards correctional treatment and rehabilitation can also increase role ambiguity and role conflict (Brown et al., 1971; Hepburn \& Albonetti, 1980; Piliavin \& Vadum, 1968; Poole \& Monchick, 1976). Given that only these latter two of the variables would contribute to deterioration of occupational health, a positive attitude towards inmate rehabilitation and social reinsertion may, overall, positively influence the occupational health of the correctional employees. However, the negative caveat already mentioned should not be ignored.

Our sample was composed of correctional employees in charge of security and inmate control at the prisons. If data had been collected from personnel in charge of rehabilitation, some of the results would most likely have been different. Regardless, the results of the present study underscore the need for correctional organizations to more adequately define the job roles of their employees, which could only have a positive impact on their occupational health.

\section{Referencias}

Brown, S. (1999). Public attitudes toward the treatment of sex offenders. Legal and Criminological Psychology, 4, 239-252. http://dx.doi.org/10.1348/135532599167879

Brown, B., et al. (1971). Staff conceptions of inmate characteristics. Criminology, 9, 316-329. http://dx.doi. org/10.1111/j.1745-9125.1971.tb00773.x

Callahan, L. (2004). Correctional officer attitudes toward inmates with mental disorders. International Journal of Forensic Mental Health, 3, 37-54. http://dx.doi.org/ 10.1080/14999013.2004.10471195

Carr-Walker, P., Bowers, L., Callaghan, P., Nijman, H., \& Paton, J. (2004). Attitudes towards personality disorders: Comparisons between prison officers and psychiatric nurses. Legal and Criminological Psychology, 9, 265-277. http://dx.doi.org/10.1348/ 1355325041719347

Chiang, M., Salazar, C., \& Núñez, A. (2007). Clima organizacional y satisfacción laboral en un establecimiento de salud estatal: Hospital tipo 1 [Organizational climate and job satisfaction in a public health center: Hospital Type 1]. Theoria, 16, 61-76.

Cullen, F. T., Latessa, E., Burton, V. S., \& Lombardo, L. (1993). The correctional orientation of prison wardens: Is the rehabilitative ideal supported? Criminology, 31,
69-92. http://dx.doi.org/10.1111/j.1745-9125.1993.tb01 122.x

Cullen, F. T., Lutze, F. E., Link, B. G., \& Wolfe, N. T. (1989). The correctional orientation of prison wardens: do officers support rehabilitation? Federal Probation, $58,33-42$.

Farkas, M. A. (1999). Correctional officer attitudes toward inmates and working with inmates in a "get tough" era. Journal of Criminal Justice, 27, 495-506. http://dx.doi. org/10.1016/S0047-2352(99)00020-3

Grau, R., Salanova, M., \& Peiró, J. M. (2000). Efectos moduladores de la autoeficacia en el estrés laboral [Modulating effects of self-efficacy in job stress]. Apuntes de Psicología, 18, 57-75.

Hepburn, J., \& Albonetti, C. (1980). Role conflict in correctional institutions. Criminology, 6, 445-459. http://dx.doi.org/10.1111/j.1745-9125.1980.tb01308.x

Hollin, C. R. (1999). Treatment program for offenders. Meta-analysis: What works, and beyond. International Journal of Law and Psychiatry, 22, 361-372. http:// dx.doi.org/10.1016/S0160-2527(99)00015-1

Jurik, N. C. (1985). Individual and organizational determinants of correctional officer attitudes toward inmates. Criminology, 23, 523-539. http://dx.doi.org/10.1111/j.1745-9125.1985.tb00352.x

Kifer, M., Hemmens, C., \& Stohr, M. K. (2003). The goals of corrections: Perspectives from the line. Criminal Justice Review, 28, 47-69. http://dx.doi.org/10.1177/ 073401680302800104

Kjelsberg, E., \& Loos, L. H. (2008). Conciliation or condemnation? Prison employees' and young peoples' attitudes towards sexual offenders. International Journal of Forensic Mental Health, 7, 95-103. http://dx.doi.org/10.1080/14999013.2008.9914406

Kjelsberg, E., Skoglund, T. H., \& Rustad, Å. B. (2007). Attitudes towards prisoners as reported by prison inmates, prison employees, and college students. $B M C$ Public Health, 7, 71-77. http://dx.doi.org/10.1186/ 1471-2458-7-71

Mansilla, F. (2011). Consecuencias del estrés de rol [Consequences of role stress]. Medicina y Seguridad del Trabajo, 57, 361-370.

Maslach, C., \& Jackson, S. (1981). The measurement of experienced burnout. Journal of Occupational Psychology, 2, 99-113. http://dx.doi.org/10.1002/job. 4030020205

Meliá. J. L., Nogareda, C., Lahera, M., Duro, A., Peiró, J. M., Salanova, M., \& Gracia, D. (2006). Principios comunes para la evaluación de los riesgos psicosociales en la empresa [Common principles for the assessment of psychosocial risks in the organization]. In J.L. Meliá, C. Nogareda, M. Lahera, A. Duro, J.M. Peiró, R. Pou, M. Salanova, D. Gracia, J.M. de Bona, J. C. Bajo, \& F. Martínez-Losa (Eds.), Perspectivas de Intervención en Riesgos Psicosociales. Evaluación de Riesgos [Perspectives in Psychosocial Risk Intervention. Risk 
Assessment](pp. 13-36). Barcelona: Foment del Treball Nacional.

Melvin, K. B,; Gramling, L. K., \& Gardner, W. M. (1985). A scale to measure attitudes toward prisoners. Criminal Justice and Behavior, 12, 241-253. http://dx.doi.org/ 10.1177/0093854885012002006

Moreno, B., Bustos, R., Matallana, A., \& Miralles, T. (1997). La evaluación del burnout. Problemas y alternativas. El CBB como evaluación de los elementos del proceso [The assessment of burnout. Issues and Options. The CBB as evaluation of process elements]. Revista de Psicología del Trabajo y las Organizaciones, 13,185-207.

Moreno, B, Sanz, A., Rodríguez-Muñoz, A., \& Geurts, S. (2009). Psychometric properties of the Spanish version of the survey work-home interaction nijmegen (SWING). Psicothema, 21, 331-337. http://www.psico thema.com/pdf/3635.pdf

Murphy, E., \& Brown, J. (2000). Exploring gender role identity, value orientation of occupation and sex of respondent in influencing attitudes towards male and female offenders. Legal and Criminological Psychology, 5, 285-290. http://dx.doi.org/10.1348/ 135532500168047

Ortet-Fabregat, G., Perez, J., \& Lewis, R. (1993). Measuring attitudes toward prisoners: A psychometric assessment. Criminal Justice and Behavior, 20, 190198. http://dx.doi.org/10.1177/0093854893020002006
Paboojian, A., \& Teske, R. H. (1997). Pre-service correctional officers: What do they think about treatment? Journal of Criminal Justice, 25, 425-433. http://dx.doi.org/10.1016/S0047-2352(97)00025-1

Philiber, S. (1987). Thy brother's keeper: A review of the literature on correctional officers. Justice Quarterly, 4, 9-37. http://dx.doi.org/10.1080/07418828700089171

Piliavin, I., \& Vadum, A. (1968). Reducing discrepancies in professional and custodial perspectives. Journal of Research in Crime and Delinquency, 3, 35-43. http:// dx.doi.org/10.1177/002242786800500103

Reisig, M. D., \& Lovrich, N. P. (1998). Job attitudes among higher-custody state prison management personnel: A cross-sectional comparative assessment. Journal of Criminal Justice, 26, 213-226. http://dx.doi.org/ 10.1016/S0047-2352(97)00079-2

Rizzo, J., House, R. E., \& Lirtzman, J. (1970). Role conflict and ambiguity in complex organizations. Administrative Science Quarterly, 15, 150-163. http://dx.doi.org/ $10.2307 / 2391486$

Schaufeli, W. B., \& Peeters, M. C. W. (2000). Job stress and burnout among correctional officers: A literature review. International Journal of Stress Management, 7, 19-48. http://dx.doi.org/10.1023/A:1009514731657

Weber, G. (1957). Conflicts between professional and nonprofessional personnel in institutional delinquency treatment. Journal of Criminal Law and Criminology, 48, 26-43. http://dx.doi.org/10.2307/1140163

Fecha de recepción: 21 de julio de 2015. Fecha de aceptación: 26 de noviembre de 2015. 